\title{
Naujagimio smegenų infarktas. Klinikinis atvejis ir literatūros apžvalga
}

\author{
R. Jakuškienė* \\ V. Joneliūnaitè** \\ U. Jucevičiuté $\dot{x}^{* *}$ \\ *Lietuvos sveikatos mokslu \\ universiteto Kauno klinikos, \\ Neonatologijos klinika \\ **Lietuvos sveikatos mokslu \\ universitetas, Medicinos fakultetas
}

\begin{abstract}
Santrauka. İvadas. Naujagimio smegenų infarktas, arba perinatalinis insultas (PI), - tai ūminis naujagimio smegenų kraujotakos sutrikimas, diagnozuojamas nuo 28-osios gestacinès savaitès ir per pirmąsias 28 dienas po gimimo su neurologine simptomatika arba be jos. Ši patologija pasireiškia tik 1 iš $1600-4000$ naujagimių, tačiau, lyginant su vyresniais vaikais, - net 6 kartus dažniau. Dèl nespecifinès neurologinès simptomatikos PI diagnostika naujagimiams yra sudètinga, todèl būtina išsiaiškinti bet kokios neurologinės simptomatikos (traukulių, raumenų tonuso pakitimų ar asimetrijos, pirminių refleksų išryškẻjimo, susilpnèjimo ar išnykimo) kilmę. Pagal naujausius literatūros šaltinius du trečdaliai insultą patyrusių naujagimių turi ryškių neurologinių ir judesio sutrikimų.

Atvejo pristatymas. Šiame straipsnyje aprašomas naujagimio smegenų išeminio infarkto atvejis, apimantis dešiniosios vidinès miego arterijos baseiną. Pažaida išsivystė per pirmąsias 12-24 valandas po gimimo su sunkia neurologine simptomatika. Pacientei buvo stebima „fechtuotojo poza“, vangumas, tačiau vienas dažniausių simptomų - traukuliai - ligos istorijoje nebuvo paminėti. Atlikus neurosonoskopijos (NSS) ir kompiuterinės tomografijos (KT) tyrimus ir jais patvirtinus diagnozę, buvo pasirinkta atlikti dekompresinę kraniotomiją (intraveninès trombolizės buvo atsisakyta dèl hemoraginio insulto rizikos).

Apibendrinimas. Ankstyva PI diagnostika yra sudètinga dèl dažniausiai nespecifinių klinikinių požymių, todèl yra ypač svarbus neurologinis ištyrimas ir instrumentiniai tyrimai. Ūmi ligos eiga reikalauja imtis skubių priemonių, kad ateityje būtų išvengta vaiko protinès ir motorinès raidos defektų.
\end{abstract}

Raktažodžiai: naujagimis, perinatalinis insultas, smegenų išemija, kraniotomija.

\section{IVADAS}

Naujagimio smegenų infarktas, arba perinatalinis insultas (PI), - tai ūminis smegenų kraujotakos sutrikimas su neurologine simptomatika, kuri dažnai būna nespecifinè. PI diagnozuojamas nuo 28-osios gestacinès savaitès ir per pirmąsias 28 dienas po gimimo. Tai reta patologija, pasireiškianti 1 iš 1600-4000 naujagimių, tačiau 6 kartus dažniau įvykstanti naujagimystėje nei vyresniems vaikams. Ligos eiga gali pasireikšti traukuliais, encefalopatija, hemiplegija ar valgymo sutrikimais [1-4]. Ši patologija rei- kalauja neatidèliotinų ir skubių veiksmų gydymo eigoje, apsaugant pacientą nuo komplikacijų. Epilepsija, hemiparezè - tai dažniausiai pasitaikančios komplikacijos. Taip pat galimi liekamieji reiškiniai, tokie kaip sutrikusi motorinè funkcija, pažintinè, emocinè, psichinè raida [5]. 2019 m. Amerikos širdies asociacijos tyrimais įrodyta, kad tik trečdaliui naujagimių po išeminio insulto pavyksta išvengti sunkių neurologinių pasekmių [6]. Šiame straipsnyje pristatomas naujagimio išeminio insulto atvejis, žaibiškai išsivystęs pirmą gyvenimo parą su sunkia neurologine simptomatika.

\author{
Adresas: \\ Vaiva Joneliūnaitè \\ Lietuvos sveikatos mokslu universitetas, \\ Medicinos fakultetas \\ A. Mickevičiaus g. 9, LT-44307 Kaunas \\ El. paštas vaiva.joneliunaite@gmail.com
}

\section{KLINIKINIS ATVEJIS}

Naujagimė iš antro nėštumo ir gimdymo, išnešiota. Gimė IIB lygio akušeriniame stacionare, natūraliais takais. Prieš gimdymą vaisiaus patologija nebuvo ịtarta, mama nèštu-

(C) Neurologijos seminarai, 2019. Open Access. This article is distributed under the terms of the Creative Commons Attribution 4.0 International License CC-BY 4.0 (http://creativecommons.org/licenses/by/4.0/), which permits unrestricted use, distribution, and reproduction in any medium, provided you give appropriate credit to the original author(s) and the source, provide a link to the Creative Commons license, and indicate if changes were made. 


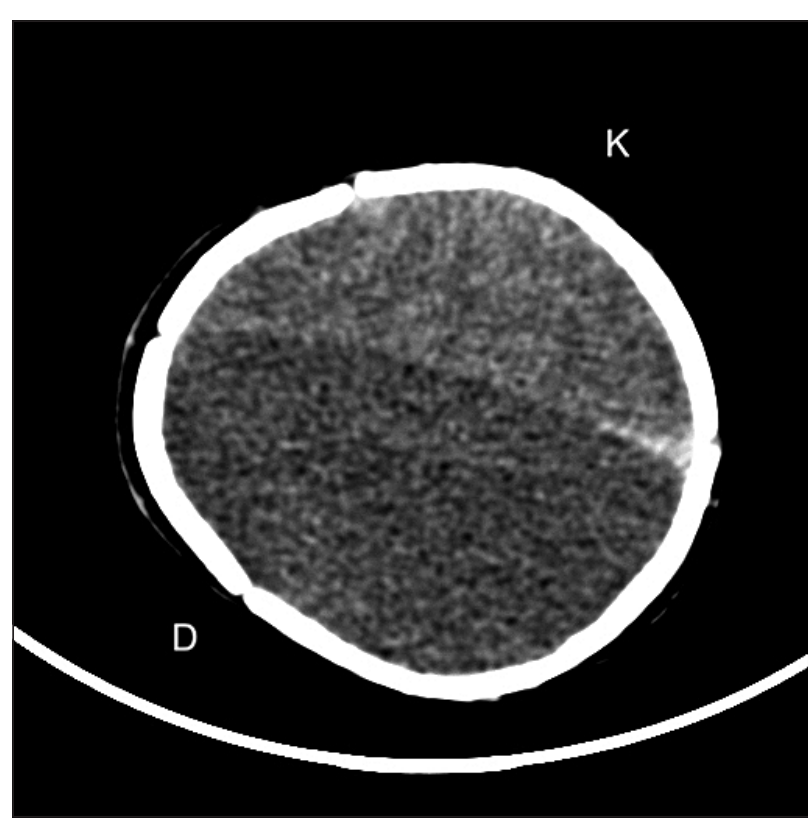

1 pav. Galvos smegenų KT be kontrasto.

Išemijos zona $a$. carotis interna dextra baseine, matoma vienpusè edema dešiniajame pusrutulyje.

mo metu akivaizdžių nusiskundimų neturejjo, kelios paros prieš gimdymą jautė stiprų skausmą pilve, kuris praejjo savaime. Naujagimès gimimo svoris - $4315 \mathrm{~g}$, pagal APGAR skalę įvertinta 9/9 balais. Palaipsniui pirmąją parą naujagimè atsisakè žįsti krūtị. Išryškèjo neurologinė simptomatika: liemuo išsilenkęs paguldžius ant kairiojo šono, pradejjo sukti galvą i dešinę pusę, kairiosios akies vyzdys nukrypo ị vidinę pusę, atsirado smulkus galūnių tremoras, fiziologiniai refleksai buvo išgaunami. Bendras kraujo tyrimas pirmą gyvenimo dieną - be uždegiminių rodiklių, hemoglobinas - $128 \mathrm{~g} / 1$. Neurosonoskopijoje (NSS) rasta vidurio linijos dislokacija ị kairę. Detalesniam ištyrimui, itariant naujagimio traukulius, antrą parą po gimimo naujagimė pervežta ị Lietuvos sveikatos mokslų universiteto ligoninès Kauno klinikų Naujagimių intensyviosios terapijos skyrių (LSMU KK NITS).

LSMU KK NITS apžiūros metu stebėta patologinė neurologinẻ būklè: naujagimè verkia spiegiančiu balsu, „fechtuotojo pozoje“ - ištiesta kairioji ranka, dešinioji ranka pritraukta prie kūno ir sulenkta per alkūnę, galva pasukta ir pakreipta ị dešinę pusę. Vyrauja raumenų hipertonusas, daugiau išreikštas rankose, oda - blyški.

Pakartota NSS - pakitęs, edemiškas dešinysis galvos smegenų pusrutulis, siauras kairysis skilvelis ir vidurio linija dislokuota ị kairę. Skubos tvarka atlikta galvos kompiuterinė tomografija (KT) - grubūs, nebenauji išeminiai pokyčiai beveik visame dešiniajame galvos smegenų pusrutulyje, normalesnė smegenų struktūra išlikusi tik kairiajame pusrutulyje. Išeminiai pokyčiai apima dešiniosios vidinès miego arterijos baseiną. Pagal ligos laiką ir KT vaizdus, buvo padaryta išvada, kad intraveninė ar intraarterinė trombolizė negalima dèl hemoraginio insulto rizikos, bet būtina atlikti dešiniosios kaukolès skliauto pusès dekompresiją dèl gyvybinių indikacijų.

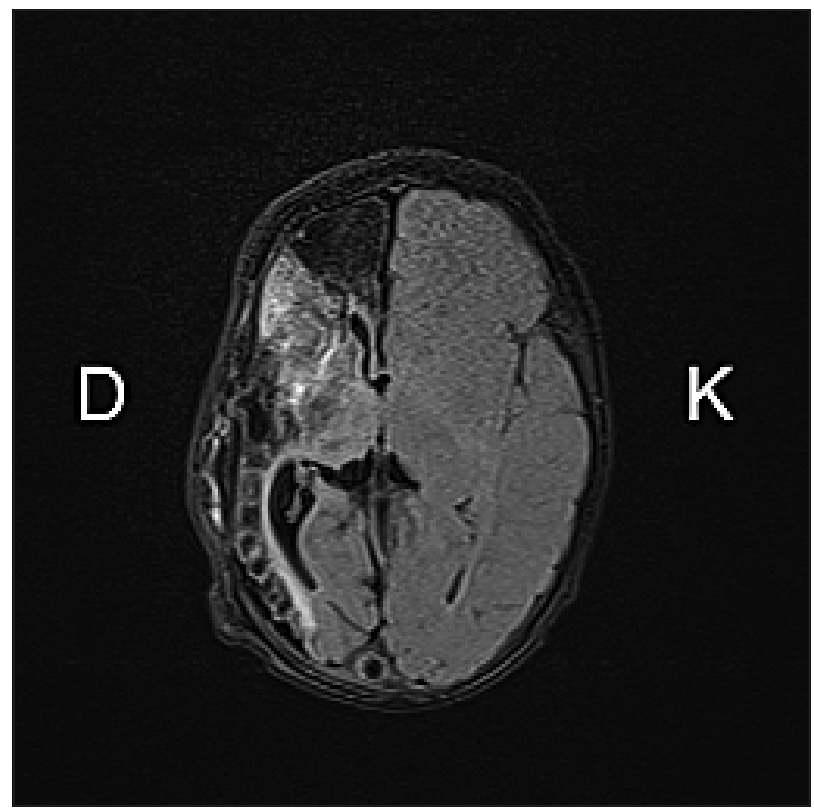

2 pav. Galvos smegenų MRT, T2W FLAIR režimas. Aksialinis pjūvis.

Cistiniai glioziniai pokyčiai dešiniajame pusrutulyje praejjus 18 parų nuo PI diagnozès ir kraniotomijos.

Tą pačią dieną konsultuota neurochirurgo. Gavus naujagimès tėvų sutikimą, buvo atlikta dekompresinè kraniotomija dešinèje, fronto parieto temporo oksipitaliai, ir šioje vietoje pašalintas kaulas. Kietasis dangalas visame dekompresijos plote supjaustytas 1-1,5 cm ilgio ịpjovomis. Operacijos metu buvo lašinama eritrocitų masè, o po jos keturias paras taikyta dirbtinė plaučių ventiliacija, stebètas kraujavimas iš plaučių. Nuskausminimui skirta fentanilio infuzija, aspirinas skirtas sustojus kraujavimui, fenobarbitalis - traukuliu profilaktikai.

Pooperaciniu laikotarpiu konsultuota: vaikų hematologo - buvo ieškoma Leideno ir protrombino mutacijų, galèjusių sąlygoti krešumo sutrikimus, paskirtas aspirinas ir geležies preparatai; vaikų kardiologo - diagnozuotas atviras arterinis latakas (AAL) ir beužsidaranti ovalioji anga.

13 dienų amžiaus apžiūrèta vaikų neurologo. Naujagimè pasisuka ị dešinę pusę, kairioji akis pakrypusi ị vidinę pusę, veido mimika išlieka simetriška. Stebèta daugiau aktyvių judesių dešinès pusès galūnėse, lyginant su ankstesne būkle (ranka buvo pritraukta prie kūno ir sulenkta per alkūnę). Raumenų tonusas ir sausgyslių refleksai išlikę stipresni kairèje pusejje. Maitinama per zondą. Atliktas VIII ir XII krešumo faktorių tyrimas atitiko normą.

Praejjus 18 paru po kraniotomijos, atlikta galvos smegenų magnetinio rezonanso tomografija (MRT). Matomi cistiniai glioziniai pokyčiai dešiniajame smegenų pusrutulyje su įvairaus laiko antrinio kraujavimo požymiais intraaksialiai ir lètinės hemoragijos intraventrikuliariai. Dèl parenchimos defekto stebima vienpusė ventrikulomegalija dèl smegenų atrofijos (2 pav.). Angiografijos režime nediferencijuojama $a$. cerebri media dextra ir sunkiai diferencijuojama $a$. cerebri anterior dextra (3 pav.).

22-ają gyvenimo dieną paciente perkelta ị Vaikų neurochirurgijos skyrių, kur pratęstas paskirtas gydymas. At- 


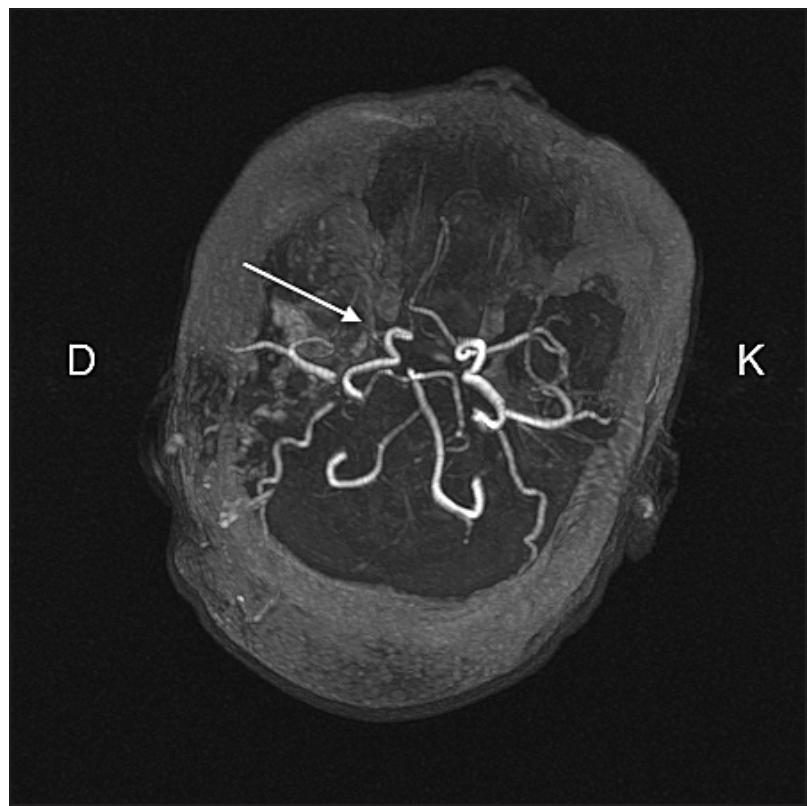

3 pav. Galvos smegenų MR angiografija, TOF/3D/art. režimas. Nediferencijuojama a. cerebri media dextra, sunkiai diferencijuojama $a$. cerebri anterior. Pokyčiai praejus 18 parų nuo PI diagnozès ir kraniotomijos.

likta pakartotinė neurochirurginė operacija dèl likvorèjos pjūvio vietoje - kietojo dangalo plastika. Pooperaciniu laikotarpiu kairiosios rankos parezė beveik nepastebima, valgo tik iš krūties, tuštinasi, šlapinasi, svoris augantis.

35 dienų amžiaus pacientei pakartota NSS - dešiniojo pusrutulio encefalomaliacijos ir atrofijos požymiai su vidurio linijos dislokacija ị dešinę. Smegenèlių kirmino hipoplazija. Apžiūrèta vaikų neurochirurgo dèl likvorejos iš pooperacinès žaizdos. Sekrecijos vietą persiuvus 3-0 siūlu,

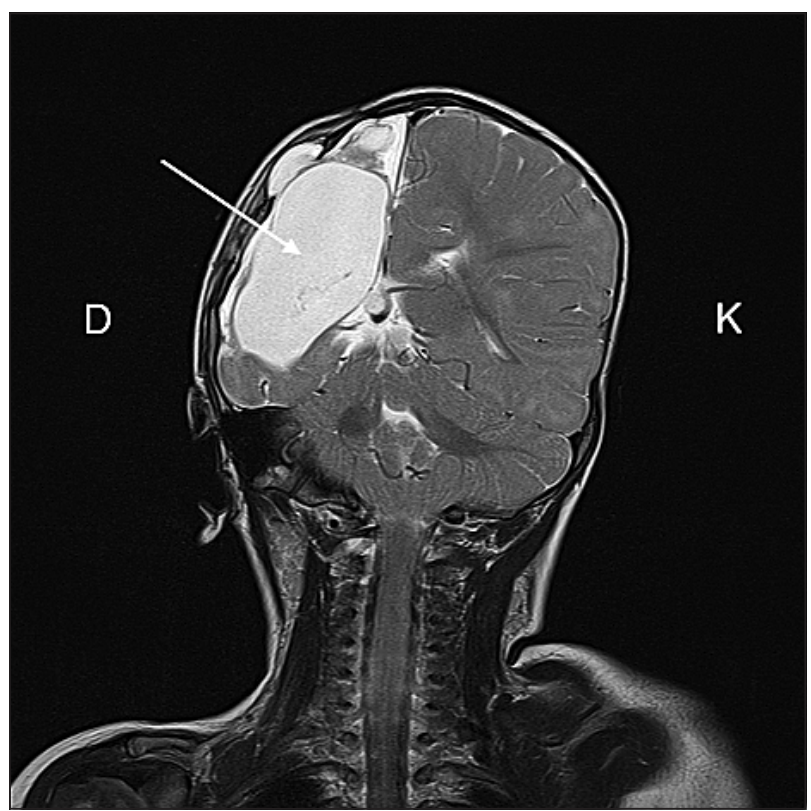

5 pav. Galvos smegenų MRT, T2W režimas. Koronarinis pjūvis. Cistiniai glioziniai pokyčiai dešiniajame pusrutulyje. Palyginus su ankstesne MRT, dešinysis pusrutulis yra mažesnis. 8 mènesiai po PI diagnozès nustatymo.

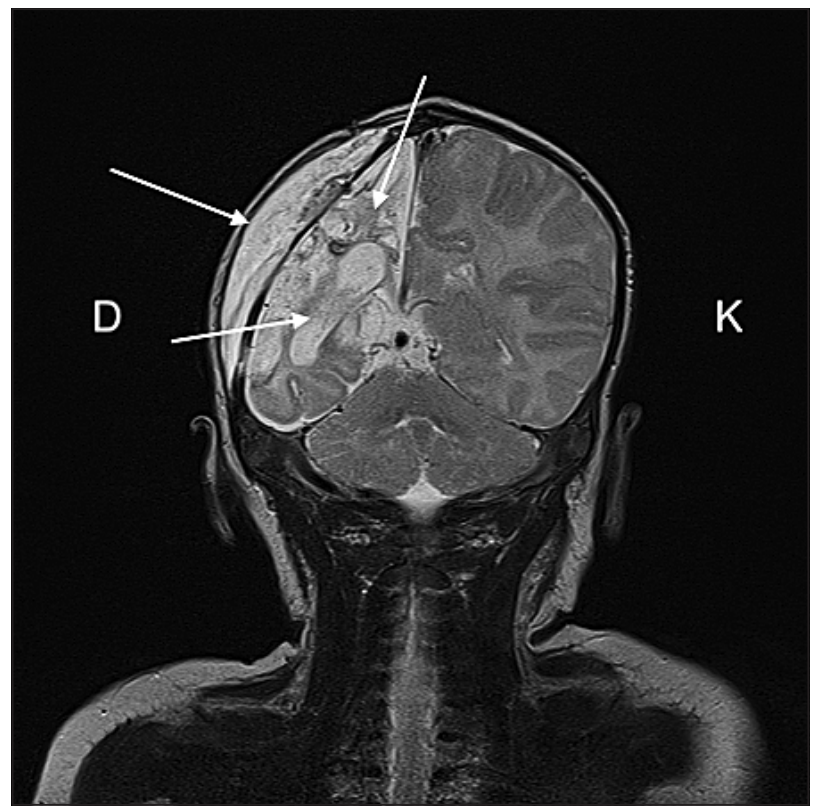

4 pav. Galvos smegenų MRT, T1W režimas. Koronarinis pjūvis. Pokyčiai praejjus 18 parų nuo PI diagnozės ir kraniotomijos. Matoma aiški atrofija dešinejje, subdurinè higroma dešinejje. Skilveliai vidutinio dydžio, asimetriški, platesnè dešinioji skilvelių sistemos pusè dèl parenchimos defekto.

likvoreja sustabdyta. Tęsiamas gydymas fenobarbitaliu (traukulių profilaktikai), acetazolamidu (smegenų skysčio kiekio mažinimui), vitaminu D3 ir kineziterapija.

45 dienų amžiuje atliktoje kontrolinėje NSS - padidèjęs požievio branduolių ir parenchimos echogeniškumas periventrikuliariai. Nežymi vidurio linijos struktūrų dislokacija ị dešinę. Lopo perrišimo metu likvorẻja nebuvo stebima, nutrauktas acetazolamido skyrimas. Gydymas aspirinu užbaigtas nesant trombofilijai būdingų pakitimų, įvertinus Leideno ir protrombino mutacijas.

Praejjus 8 mėnesiams, pakartotas MRT tyrimas be kontrastinès medžiagos, kuriame stebima mažesnès apimties dešinysis pusrutulis su cistiniais glioziniais pokyčiais ir hemosiderino depozitais bei ryškesnè komunikuojanti hidrocefalija. İvertinta psichomotorinė raida - be didesnių sutrikimų, išskyrus neryškų spastiškumą kairiojoje rankoje.

Dabartinis pacientės tyrimų, gydymo ir profilaktikos planas yra prižiūrimas daugiadisciplininès komandos (pediatro, neurochirurgo, kineziterapeuto, ergoterapeuto, logopedo, psichologo ir socialinio darbuotojo).

\section{LITERATŪROS APŽVALGA}

\section{Epidemiologija}

Naujagimio smegenų infarktas yra reta patologija, dažnesnė neišnešiotiems nei laiku gimusiems naujagimiams. Išskiriamas išeminis, hemoraginis, smegenų veninių sinusų trombozès ir periventrikulinis veninis smegenų infarktas. Naujagimiams dažniausias yra išeminis arterinis smegenų 
infarktas (IASI). Skirtingų šaltinių duomenimis, naujagimio smegenų infarkto dažnis siekia 1 atveji iš 1600-4000 naujagimių [3, 4]. Paplitimą nustatyti sunku dèl skirtingų klinikinių ir diagnostinių kriterijų bei didelès imties tyrimų trūkumo. Lietuvoje epidemiologinių tyrimų PI tema nėra atlikta, tačiau šios patologijos paplitimas Estijoje siekia 63 atvejus 100000 naujagimių [6].

\section{Etiologija}

IASI priežastis dažnai išlieka neaiški. Remiantis literatūros duomenimis, išskiriami vaisiaus, motinos ir placentos patologijos sąlygoti rizikos veiksniai. Motinos rizikos veiksniai apima koaguliacijos sutrikimus, tokius kaip V Leideno faktoriaus genetinès mutacijos, suaktyvejusi protrombino gamyba. $68 \%$ motinų ir $60 \%$ naujagimių su perinatalinio išeminio insulto diagnoze turejo protrombino funkcijos sutrikimų [7]. Tai leidžia daryti prielaidą, kad koaguliacijos sutrikimai motinos organizme gali sąlygoti PI. Vis dėlto yra ir kitų svarbių rizikos veiksnių - preeklampsija, nevaisingumas, rūkymas, intrauterinio augimo sulètėjimas, oligohidramnionas, karščiavimas gimdymo metu $>38^{\circ} \mathrm{C}$, vakuumekstrakcija, replių naudojimas gimdymui, virkštelès anomalijos, asfiksija, skubi cezario pjūvio operacija, mekonijus vaisiaus vandenyse, virkštelès arterinis $\mathrm{pH}<7,1$, naujagimio gaivinimas po gimimo [8]. Tarp vaisiaus rizikos veiksnių dažnai išskiriamas neišnešiotumas, kuris didina riziką iki 2,38 karto, ir ịimta širdies yda. Nustatyta, kad rizika išlieka ir atlikus ydos operaciją [9, 10]. Trombofilija, C reaktyvaus baltymo trūkumas, APGAR $<7$ po 5 minučių, vaisiaus širdies ritmo sutrikimai, hipoglikemija taip pat yra svarbūs PI atsiradimui. Remiantis literatūra, bent vienas rizikos veiksnys nustatomas $38 \%$ naujagimių su PI diagnoze [6].

\section{Simptomai}

IASI yra ūmi būklè, kuri išnešiotiems kūdikiams paprastai yra simptominé, tačiau klinikiniai požymiai - nespecifiniai. Dažniausiai (nuo 60 iki 90 \% atvejų) naujagimiams stebimi traukuliai (tiek generalizuoti, tiek židininiai) ir letargija, kurie pasireiškia per pirmąsias 12-72 gyvenimo valandas $[11,12]$. Esant vienpusiam smegenų pažeidimui, pasireiškia kontralateraliniai traukuliai. Literatūros duomenimis, smegenų infarktas patvirtinamas $12 \%$ naujagimių, kuriems stebimi traukuliai [13]. Tačiau traukuliai pasireiškia ir esant kitoms priežastims: naujagimių encefalopatijai, neuroinfekcijoms, kraujosrūvoms, igimtoms medžiagų apykaitos ligoms. Kiti nespecifiniai simptomai, kurie stebimi esant smegenų infarktui, - apnejja, raumenų tonuso padidejjimas ar sumažėjimas, dirglumas, valgymo sutrikimai [14]. Klinika yra ryškiausia esant vidurinès smegenų arterijos (a. cerebri media (ACM)) išemijai, kuri pasireiškia apie $50 \%$ visų perinatalinio infarkto atvejų [15]. Esant ACM išemijai, simptomai būna ryškesni veide ir būdinga hemiparezè. Esant abipusiam pažeidimui, galima kvadriplegija. Neišnešiotiems naujagimiams PI eiga dažniausiai būna asimptomè [16].

\section{Diagnostika}

IASI nustatomas esant smegenų išemijos požymiams neuroradiologiniuose vaizduose. MRT DWI (angl. diffusion weighted imaging) režimas yra pats jautriausias PI diagnostikoje ir turètų būti atliktas kuo greičiau visiems naujagimiams esant stabiliai būklei ir PI įtarimui [17]. Ankstyvas infarktas vizualizuojamas geriau su DWI, nei naudojant ịprastą MRT. Pirmosiomis valandomis po pažeidimo stebimas didelis signalo intensyvumas DWI režimu, galimai dẻl citotoksinès edemos ar nekrozès, kartu su difuzijos koeficiento sumažèjimu. Atliekant MRT DWI, geriausias laikas įvertinti PI pokyčius yra 2-4 dienos po pažeidimo [18]. Išnešiotiems naujagimiams diagnozuojant ligą vẻliau nei 7 paros po pažeidimo, rekomenduojama atlikti MRT T2 ir FLAIR režimais. Didelis pleišto formos pažeidimas, įtraukiantis ir smegenų žievę, yra būdingas pagrindinių smegenų arterijų okliuzijai, ypač vidurinès smegenų arterijos embolijai ar trombozei. Atsižvelgiant į MRT skirtingų režimų galimybes, vertinant smegenų hemodinamiką ir kraujagysliu anatomiją, ịtarus PI visada MRT rekomenduojama atlikti DWI, SWI, GRE, T1 ir T2 režimais. Taip pat į naujagimio ištyrimą turètų būti ịtraukta ir magnetinio rezonanso angiografija, kuri leidžia nustatyti igimtą kraujagyslių patologiją, miego arterijų disekaciją. MRT yra pranašesnis nei KT dèl mažesnès radiacijos ir jautresnès diagnostikos, ypač esant naujai atsiradusiems pažeidimams. Neturint galimybės atlikti skubaus MRT ar esant ūmiems pakitimams, tikslinga atlikti neurosonoskopijos (NSS) tyrimą, siekiant atmesti kitas patologijas. NSS yra greita, neturinti spinduliuojančios jonizuotès, lengvai atliekama ir leidžia pamatyti išemines hiperechogeniškas zonas, ypač ūmioje PI fazėje. Taip pat matomos hipoechogeniškos zonos, esant lètiniams pažeidimams. Tačiau NSS yra mažai jautri ir, esant PI, per pirmąsias tris dienas diagnozuojama $68 \%$ atvejų, o 4-10 dienomis jautrumas padideja iki $87 \%$. KT privalumas yra greitas tyrimo atlikimo laikas, vaikams dažniausiai nereikalinga bendrinė nejautra, atliekant tyrimą. Vis dèlto, rekomenduojama vengti ir mažinti KT naudojimą naujagimiams dèl žalingo jonizuojančios spinduliuotès poveikio. Mažiau nei prieš 24 valandas įvykęs pažeidimas KT gali būti nediferencijuojamas. Tokiu atveju smulkūs sumažejusio tankio pažeidimo židiniai būna dengiami mažo tankio besivystančių smegenų nemielinizuotos baltosios medžiagos [19].

Vertinant traukulių etiologiją, auksinis standartas elektroencefalografija (EEG). Ji leidžia diferencijuoti PI nuo kitų patologijų, įskaitant ir infekcinius susirgimus. Esant foninio aktyvumo pakitimams, galima daryti prielaidą, kad yra generalizuotas smegenų pažeidimas ir tikėtina, kad naujagimiui išsivystys hemiparezė [20].

\section{Gydymas}

Amerikos širdies asociacija nurodo, kad pagrindinis IASI gydymas - simptominis. Didžiausias demesys turètų būti skiriamas smegenų edemos valdymui, todèl dažniausiai pasirenkama dekompresinė kraniotomija, ypač esant 
a. cerebri media sindromui. Taip pat simptomiškai gydomi traukuliai, užtikrinama oksigenacija, hidratacija ir dažnai pasireiškianti anemija [2]. Skubi reperfuzija, esant arterinei išemijai, naujagimiams netaikoma. Reperfuzijos galimybės yra ribotos dèl mažo arterijų skersmens ir naujagimiams pritaikytų endoskopinių prietaisų trūkumo. Tačiau šis gydymo metodas pritaikomas vyresniems vaikams, esant arterijų išemijai [21]. Traukuliams gydyti taikomi antikonvulsiniai vaistai. Klinikinejje praktikoje dažniausiai vartojami fenobarbitalis ir fenitoinas. Remiantis Cochrane sisteminès apžvalgos rezultatais, abu šie vaistai yra panašiai efektyvūs mažiau nei pusei tiriamųjų (sąlyginė rizika 0,40 $95 \%$ ). Tačiau po 1 metų vaistų vartojimo visiems tiriamiesiems pasireiškẻ lengvi arba sunkūs neurologinio vystymosi sutrikimai. Remiantis esama literatūra, negalima konstatuoti, kuris vaistas yra efektyvesnis, gydant traukulius. Taip pat trūksta klinikinių atsitiktinių imčių tyrimų, kurie įrodytų antikonvulsinių vaistų naudą [22].

Remiantis literatūros duomenimis, antitrombocitinis ar antikoaguliacinis gydymas aspirinu, nefrakcionuotu heparinu ar mažos molekulinès masės heparinu naujagimiams su IASI diagnoze nerekomenduojamas dèl mažos IASI pasikartojimo tikimybès ir padidejusios hemoraginių komplikacijų rizikos. Tačiau vaikams, turintiems didelę pasikartojimo riziką (sergantiems trombofilija, igimtomis širdies ydomis), gydymas antitrombociniais ir antikoaguliaciniais vaistais yra taikomas [2].

Svarbu suteikti pacientams tinkamas reabilitacijos galimybes. Literatūroje rekomenduojama naujagimiams po PI taikyti GAME (angl. Goals, Activity, Motor Enrichment) reabilitacijos metodą. Nustatyta, kad, taikant ši metodą, pacientų motoriniai igūdžiai po 6-9 mẻnesių reabilitacijos buvo geresni, lyginant su standartinemis reabilitacijos priemonemis [23].

\section{Išeitys}

Išeitys po PI tiesiogiai koreliuoja su smegenų pažeidimo plotu. Daugumai pacientų po PI išsivysto ilgalaikiai neurologiniai sutrikimai, todèl reabilitacija yra būtina, siekiant pagerinti pacientų gyvenimo kokybę. 50-60\% naujagimių po IASI per pirmuosius gyvenimo metus pasireiškia motorinès funkcijos sutrikimai su dominuojančia hemipareze, labiau išreikšta viršutinėje nei apatinèje galūnèje [12]. Atsitiktinès atrankos būdu kontroliuojami tyrimai parodè, kad transkranijinès magnetinès stimuliacijos ir transkranijinès nuolatinès srovès stimuliacijos gali būti efektyvios siekiant pagerinti prarastą viršutinès galūnès funkciją, kas leistų pagerinti ilgalaikes PI patyrusių pacientų išeitis [24].

Epilepsija yra dažnesnè vaikams, kuriems PI simptomatikoje dominavo traukuliai ir esant smegenų žievės pažeidimui. Ligos dažnis varijuoja nuo $6 \%$ atvejų, esant hemoraginiam PI, iki 40-60 \% atvejų po IASI [12]. Epilepsija yra susijusi su prastesnėmis pažintinėmis funkcijomis, sutrikusiu neurologiniu vystymusi. Atlikti tyrimai parodè, kad vaikai, kuriems po PI išsivystė epilepsija, turi reikšmingai mažesnị IQ, lyginant su bendraamžiais, kuriems po PI epilepsija nepasireiškė [25].
Kalbos vystymasis $90 \%$ atvejų išlieka normalus, o verbalinis IQ atitinka normos ribas. Vis dèlto, vaikai su dešiniojo pusrutulio pažeidimu gali turèti verbalinès ekspresijos sunkumų, o paaugliai ir suaugusieji, lyginant su kontrole, esant kairiojo pusrutulio pažeidimams daro daugiau morfologijos klaidų, vartoja paprastesnị žodyną [12].

Esant PI, taip pat pasireiškia regos lauko pažeidimai. Remiantis amerikiečių atlikta kohortine studija, ị kurią buvo įtraukti 138 naujagimiai, dažniausias regos sutrikimas, lydintis PI, yra hemianopsija, taip pat 38 vaikams išsivystė aklumas [26].

Pakartotinio insulto dažnis siekia $3 \%$, tačiau, esant igimtai širdies ydai, pasikartojimo dažnis per pirmuosius 10 metu po PI siekia $27 \%[27,28]$.

Svarbu atkreipti dèmesị ir ị komplikacijas, kurios turi ịtakos tèvų psichologinei būsenai. Stebimas proporcingas pažeidimui padidèjęs streso, nerimo lygis, suprastėjusi gyvenimo kokybė. Nerimas gali sustiprèti, kai PI priežastys yra neaiškios. Neretai, tokiu atveju, motinos ima kaltinti save, kas gali sukelti potrauminio streso sindromą, depresiją ir turèti pasekmių visai šeimai [29]. Siekiant išvengti tokių pasekmių, rekomenduojama paaiškinti tẻvams, kad PI prevencijos galimybės yra labai ribotos ir mama nėra kalta dẻl išsivysčiusio PI.

\section{APIBENDRINIMAS}

Naujagimio smegenų infarktas, arba PI, yra reta, tačiau sunki patologija dèl profilaktikos stokos, sudètingos diagnostikos ir galimų ilgalaikių komplikacijų. Literatūroje aprašomos ilgalaikès sunkios PI išeitys: epilepsija, kognityviniai ir elgesio sutrikimai, sumažèjęs intelektas, regos sutrikimai [12, 21, 22]. Aprašomi ir tėvų, kurių vaikas patyrè PI, padidèjęs streso, nerimo lygis ir reikšmingai sumažejjusi gyvenimo kokybé, kuri proporcinga vaiko negaliai [25]. Nesant efektyvių prevencijos priemonių, didžiausias dèmesys turètų būti skiriamas ankstyvai diagnostikai ir reabilitacijos organizavimui, siekiant išvengti ilgalaikių komplikacijų.

Aprašytame klinikiniame atvejyje akivaizdi židininė neurologinė simptomatika leido ịtarti PI. Naujagimei pirmają parą pasireiškẻ būdingi neurologiniai simptomai: hipertonusas, verksmas spiegiančiu balsu, „fechtuotojo poza“ - ištiesta kairioji ranka, dešinioji ranka pritraukta prie kūno ir sulenkta per alkūnę, galva pasukta ir pakreipta ị dešinę pusę, odos blyškumas. Tačiau pagrindiniai literatūroje aprašomi simptomai - traukuliai, letargija, encefalopatija - stebimi nebuvo.

PI gydymas naujagimiams išlieka simptominis, didžiausią dėmesį skiriant traukuliams gydyti ir tinkamai oksigenacijai bei hidratacijai užtikrinti. Svarbu igyvendinti ir tinkamą reabilitacijos planą, kuris itin pagerina ilgalaikes pacientų išeitis. Sisteminių apžvalgų, metaanalizių šia tema trūkumas leidžia svarstyti apie skirtingą gydymo taktiką konkrečiu PI atveju. 


\section{Literatūra}

1. Armstrong-Wells J, Ferriero D. Diagnosis and acute management of perinatal arterial ischemic stroke. Neurol Clin Pract 2014; 4(5): 378-85. https://doi.org/10.1212/CPJ 0000000000000077

2. Ferriero D, Fullerton H, Bernard T, Billinghurst L, Daniels S, DeBaun M, et al. Management of stroke in neonates and children: a scientific statement from the American Heart Association/American Stroke Association. Stroke 2019; 50(3): e51-96. https://doi.org/10.1161/STR. 0000000000000183

3. Lynch J, Nelson K. Epidemiology of perinatal stroke. Curr Opin Pediatr 2001; 13(6): 499-505. https://doi.org/10.1097/ 00008480-200112000-00002

4. Laugesaar R, Kolk A, Tomberg T, Metsavaht T, Lintrop M, Varendi $\mathrm{H}$, et al. Acutely and retrospectively diagnosed perinatal stroke. Stroke 2007; 38(8): 2234-40. https://doi.org/10.1161/STROKEAHA.107.483743

5. Ichord R. Stroke in the newborn: management and prognosis [Internet]. UpToDate. 2019 [Žiūrèta 2019-10-18]. Prieiga per internetą: https://www-uptodate-com/contents/strokein-the-newborn-management-and-prognosis? search= neonatal $\% 20$ stroke \& topicRef $=6157 \&$ source $=$ see_link\# H3984246688

6. Sreenan C, Bhargava R, Robertson C. Cerebral infarction in the term newborn: clinical presentation and long-term outcome. J Pediatr 2000; 137(3): 351-5. https://doi.org/ $10.1067 / \mathrm{mpd} .2000 .107845$

7. Simchen M, Goldstein G, Lubetsky A, Strauss T, Schiff E, Kenet G. Factor V Leiden and antiphospholipid antibodies in either mothers or infants increase the risk for perinatal arterial ischemic stroke. Stroke 2009; 40(1): 65-70. https://doi.org/10.1161/STROKEAHA.108.527283

8. Li C, Miao J, Xu Y, Hua Y, Ma Q, Zhou L, et al. Prenatal, perinatal and neonatal risk factors for perinatal arterial ischaemic stroke: a systematic review and meta-analysis. Eur J Neurol 2017; 24(8): 1006-15. https://doi.org/10.111/ ene. 13337

9. Sorg A, Kries R, Klemme M, Gerstl L, Weinberger R, Beyerlein A, et al. Risk factors for perinatal arterial ischaemic stroke: a large case-control study. Dev Med Child Neurol 2019 Sep 5. [Epub ahead of print]. https://doi.org/ $10.1111 /$ dmcn. 14347

10. Miller S, McQuillen P, Hamrick S, Xu D, Glidden D, Charlton N, et al. Abnormal brain development in newborns with congenital heart disease. N Engl J Med 2007; 357(19): 1928-38. https://doi.org/10.1056/NEJMoa067393

11. Ecury-Goossen G, Raets M, Lequin M, Feijen-Room, Govaert P, Dudink J. Risk factors, clinical presentation, and neuroimaging findings of neonatal perforator stroke. Stroke 2013; 44(8): 2115-20. https://doi.org/10.1161/ STROKEAHA.113.001064

12. Dunbar M, Kirton A. Perinatal stroke: mechanisms, management, and outcomes of early cerebrovascular brain injury. Lancet Child Adolesc Health 2018; 2(9): 666-76. https://doi.org/10.1016/S2352-4642(18)30173-1

13. Estan J, Hope P. Unilateral neonatal cerebral infarction in full term infants. Arch Dis Child Fetal Neonatal Ed 1997; 76(2): F88-93. https://doi.org/10.1136/fn.76.2.F88

14. Lynch J. Epidemiology and classification of perinatal stroke. Semin Fetal Neonatal Med 2009; 14(5): 245-9. https://doi.org/10.1016/j.siny.2009.07.001

15. Govaert P, Ramenghi L, Taal R, de Vries L, Deveber G. Diagnosis of perinatal stroke I: definitions, differential diagno- sis and registration. Acta Paediatr 2009; 98(10): 1556-67. https://doi.org/10.1111/j.1651-2227.2009.01461.x

16. Lehman L, Rivkin M. Perinatal arterial ischemic stroke: presentation, risk factors, evaluation, and outcome. Pediatr Neurol 2014; 51(6): 760-8. https://doi.org/10.1016/ j.pediatrneurol.2014.07.031

17. Raju T, Nelson K, Ferriero D, Lynch J. Ischemic perinatal stroke: summary of a workshop sponsored by the National Institute of Child Health and Human Development and the $\mathrm{Na}$ tional Institute of Neurological Disorders and Stroke. Pediatrics 2007; 120(3): 609-16. https://doi.org/10.1542/ peds.2007-0336

18. Husson B, Durand C, Hertz-Pannier L. Recommandations concernant l'imagerie de l'accident vasculaire cérébral ischémique du nouveau-né. Archives de Pédiatrie 2017; 24(9): 9S19-27. https://doi.org/10.1016/S0929. 693X(17)30327-5

19. Lee S, Mirsky D, Beslow L, Amlie-Lefond C, Danehy A, Lehman L, et al. Pathways for neuroimaging of neonatal stroke. Pediatr Neurol 2017; 69: 37-48. https://doi.org/ 10.1016/j.pediatrneurol.2016.12.008

20. van der Aa NE, Dudink J, Benders MJ, Govaert P, van Straaten HL, Porro GL, et al. Neonatal posterior cerebral artery stroke: clinical presentation, MRI findings, and outcome. Dev Med Child Neurol 2013; 55(3): 283-90. https://doi.org/10.1111/dmcn.12055

21. Rivkin M, Bernard T, Dowling M, Amlie-Lefond C. Corrigendum to 'Guidelines for urgent management of stroke in children' [Pediatric Neurology 56 (2016) 8-17]. Pediatr Neurol 2016; 64: 105. https://doi.org/10.1016/ j.pediatrneurol.2016.08.019

22. Booth D, Evans D. Anticonvulsants for neonates with seizures. Cochrane Database Syst Rev 2004; (4): CD004218. https://doi.org/10.1002/14651858.CD004218.pub2

23. Morgan C, Novak I, Dale R, Guzzetta A, Badawi N. Single blind randomised controlled trial of GAME (Goals - Activity - Motor Enrichment) in infants at high risk of cerebral palsy. Res Dev Disabil 2016; 55: 256-67. https://doi.org/ 10.1016/j.ridd.2016.04.005

24. Gillick B, Rich T, Nemanich S, Chen C, Menk J, Mueller B, et al. Transcranial direct current stimulation and constraintinduced therapy in cerebral palsy: a randomized, blinded, sham-controlled clinical trial. Eur J Paediatr Neurol 2018; 22(3): 358-68. https://doi.org/10.1016/j.ejpn.2018.02.001

25. Vuillerot C, Marret S, Dinomais M. Devenir neurodéveloppemental après un infarctus cérébral artériel néonatal. Archives de Pédiatrie 2017; 24(9): 9S51-60. https://doi.org/10.1016/S0929-693X(17)30332-9

26. Crawford L, Golomb M. Childhood stroke and vision: a review of the literature. Pediatr Neurol 2018; 81: 6-13. https://doi.org/10.1016/j.pediatrneurol.2017.11.007

27. Lehman L, Beaute J, Kapur K, Danehy A, Bernson-Leung M, Malkin $\mathrm{H}$, et al. Workup for perinatal stroke does not predict recurrence. Stroke 2017; 48(8): 2078-83. https://doi.org/ 10.1161/STROKEAHA.117.017356

28. Rodan L, McCrindle B, Manlhiot C, MacGregor D, Askalan R, Moharir M, et al. Stroke recurrence in children with congenital heart disease. Ann Neurol 2012; 72(1): 103-11. https://doi.org/10.1002/ana.23574

29. Bemister T, Brooks B, Dyck R, Kirton A. Predictors of caregiver depression and family functioning after perinatal stroke. BMC Pediatr 2015; 15: 75. https://doi.org/10.1186/ s12887-015-0397-5 
R. Jakuškienė, V. Joneliūnaitė, U. Jucevičiutė

\section{STROKE IN THE NEWBORN. CLINICAL REPORT AND LITERATURE REVIEW}

\section{Summary}

Background. Stroke in the newborn or perinatal stroke (PS) is an acute brain ischemia with the duration up to the first 28 days of life with neurological symptoms or without them. Therefore, the diagnostics in clinical practice can become tricky due to misleading expression of this clinical syndrome. Whilst rare (1 in $1600-4000$ cases), PS has 6 times higher prevalence in newborns compared to older children. Consequently, slight neurological symptoms such as convulsions, changes or asymmetry in muscle tone, exaggeration, weakening or disappearance of primitive reflexes should be taken into account urgently. According to American Heart Association's studies in 2019, two thirds of perinatal victims have neurological disability or delayed mental performance.

Case report. In this article we present a clinical case of perinatal ischemic stroke and literature review. We analyze acute brain ischemia in a newborn which developed during the first 12-24 hours of life with severe neurological symptoms and involved the area of the right internal carotid artery. Apart from "fencing reflex" and feeding rejection, epilepsy was not marked in the history of PS onset. The doctors agreed on the diagnosis based on neurosonography and computed tomography results, and the decision of performing craniotomy was made due to the risk of hemorrhagic stroke.

Conclusions. Diagnosing perinatal stroke is a crucial and difficult task for all pediatricians because of its poor clinical expression and the necessity of urgent actions in order to avoid long term outcomes. Hence, thorough neurological exam and neuroimaging is an essential point in early diagnostics. Clinical practice reveals that there are no common guidelines to diagnose and manage perinatal stroke as an extremely urgent pathology which has a significant impact on a child's further mental development.

Keywords: newborn, perinatal stroke, brain ischemia, craniotomy.

Gauta:

Priimta spaudai:

20191104 20200115 